\title{
Similarities in Textual Contents between Burung Simbangan Poetry and Siti Zubaidah Poetry
}

\author{
Rustam Effendi \\ Lambung Mangkurat University, Banjarmasin, Indonesia
}

\begin{abstract}
One of the scripts stored in the Lambung Mangkurat Museum, Kalimantan Selatan Province, is Burung Simbangan Poetry. The interesting part is that this script has several similarities to Siti Zubaidah Poetry. This research is a philological study, of which the research aims to reveal the existence of a script amidst the owner's ethnicity. The method applied to understand these scripts is a qualitative method using a content analysis technique. The data source comprises both of scripts documents. The findings of this study include several similarities in the narrative between Burung Simbangan Poetry and Siti Zubaidah Poetry. These similarities are the stories about (i) a protagonist who has multiple wives; (ii) a first wife (the oldest), who assists her husband in a war until victory; (iii) a first wife (the oldest), who disguises herself as a man; (iv) a protagonist who is imprisoned in a poisonous well; (v) a protagonist who is hit by a chained arrow; (vi) the oldest wife, who assists her husband in reclaiming a young wife kidnapped by an enemy; and (vii) a protagonist assisted by four loyal patih, or commanders.
\end{abstract}

Index Terms—myth, legend, philology, Burung Simbangan Poetry, Siti Zubaidah Poetry

\section{INTRODUCTION}

One of the scripts stored in Lambung Mangkurat Museum, Kalimantan Selatan Province, Banjarbaru, is Burung Simbangan Poetry. It is a Banjar classic written in Jawi letters by an anonymous author. From the language and paper used, this poem is believed to have been written in the early 1800s or early 1900s. Meanwhile, from its content, which is filled with India-Hindu nuance, this poem can be considered a literary work under the influence of India-Hindu. The script of Burung Simbangan Poetry has 1003 stanzas.

One interesting factor is that this script bears several similarities to Siti Zubaidah Poetry, while if it is examined according to genre and period, these two scripts are very distinct. According to genre, Burung Simbangan Poetry is categorized as myth, while Siti Zubaidah Poetry is legend. According to time period, Burung Simbangan Poetry is a part of Banjar classical literature from the age of India-Hindu and Siti Zubaidah Poetry is part of Banjar classical literature from the age of transition from Hinduism to Islam.

Syair Siti Zubaidah is well-known in Kalimantan Selatan. In the 1970s, this poem was performed every Saturday night on Radio Republik Indonesia (RRI) Banjarmasin by Ms. Saniah. At this time, in villages, people gathered in the homes of those rich enough to have radios. They came there with one purpose: to listen to Syair Siti Zubaidah performed by Ms. Saniah.

Similar to Burung Simbangan Poetry, Siti Zubaidah Poetry was also written in the Jawi alphabet. The Melayu scripts, especially those stored in Lambung Mangkurat Museum, are mostly written in the Jawi alphabet, as only the few educated people in Banjar were able to write using Latin letters. Most people were illiterate of the Latin alphabet but knew the Jawi alphabet.

These people learned the Jawi alphabet from religious teachers directly at these teachers' houses. In these houses, they also learned about Islam. During this period, Islamic holy books were written in the Jawi alphabet. Therefore, with their knowledge of the Jawi alphabet, written communication, including letters from teachers to their disciples and literary works in this era, were also written in the Jawi alphabet. Sometimes, the scripts written in the Jawi alphabet were also called Jawi books. This paper aims to compare Burung Simbangan Poetry and Siti Zubaidah Poetry.

\section{RESEARCH METHOD}

This study used a qualitative method with the texts as the primary data source. To understand these texts, the researcher applied a hermeneutic approach and content analysis technique. A hermeneutic approach is an approach that prioritizes persistence and accuracy in reading texts. Repeatedly reading texts is a method used to grasp the meaning along with the details and that takes those details into account, as well. This approach is inseparable from the content analysis technique. Krippendrorff (2004) stated that content analysis is "a research technique for making replicable and valid inferences from texts (or other meaningful matter) to the contexts of their use".

The hermeneutic approach and the content analysis technique are interconnected. How content analysis works, which is known as hermeneutic circles, becomes how hermeneutics works in order to understand the messages of a text. Krippendrorff (2004) argued that "The analysts acknowledge working within hermeneutic circles in which their own socially or culturally conditioned understanding constitutively participate". The hermeneutic circle is an observation 
and thorough reading of textual contents to understand the overall content of the text. The observation and thorough reading of the text followed by partial observation and reading of the text is continuously repeated; therefore, this activity is similar to an unsaturated circle. The saturation ends when the essential meaning of the text is considered precise.

In relation to the hermeneutic circle, Ricoeur (2012) restated three important aspects in attempts at interpreting, defining, and explaining a text. These three aspects include: (i) to interpret the text's verbal meaning is to interpret it wholly; (ii) defining a text is to define it as an individual; and (iii) a literary text involves a horizon of potential meanings, which can be actualized in many different ways.

\section{LITERATURE REVIEW}

Burung Simbangan Poetry and Siti Zubaidah Poetry are the inheritance of Banjar classical literature in the form of texts. Usually in literary studies, classical literature in the form of scripts is first studied by philologists using their philological theories. These philologists are at the vanguard of textual research. Robson (1994) argued that for classical literary works to be "read and comprehended", two things can be done: to present and interpret the multiple meanings contained within the text itself.

Philology originates from a Greek word of philos or 'love' and logos or 'word' and is commonly affiliated with the study of textual content or meaning of an ancient script (Sudjiman, 1995). This ancient script was composed by an ancient community. Due to these inherited scripts, today's generation can acknowledge the life in the past. The scripts depict the overview of a past culture, the culture of the ancestors of a nation. Philology attempts to reveal the cultural products of a nation through the study of language used in the written inheritance (Baried, 1985). Some types of culture of an old community (traditional community) are discussed in classical scripts. These classical texts comprising traditional people's culture are called scripts.

Philological studies require the patience and precision of researchers. In studying a script, the only data source is the script itself. The author and the society it was written in and existed in are no longer valid due to the passing of generations and time. Effendi (2017) argued that humans who supported a culture no longer exist due to changes in ages and generations; however, because of their legacy in the form of readable scripts, the traces of their culture from time to time can be perceived and understood by the next generations. From these scripts, the next generation can understand and inherit the values of humanity, spirituality, views of life, skills, and other legacies that are supposed to be known and embraced. Different from modern literary works, other than the work itself as a research data source, researchers can still perceive the community of readers and other cultural environments that lived together with these literary works. In other words, the interpretation of modern literary works is easier and more certain than the interpretation of ancient literary works. However, the result of a study or research is truly determined by the researchers' integrity.

Other than the absence of a possible interaction between the researcher and other data sources but the script, the researcher also faces another obstacle, which is the fact that generally the script was oral. It is uncertain exactly when these oral stories were transcribed by a copyist as a written script. Ikram (1997) argued that the birth of classical or traditional literature is very different from the birth of a modern literary work. In the traditional world, the connection between literature and the society it was born in is very close. The literature circulated within the community and became theirs until it was written down. It was clear that the line between oral and written literature was blurry.

Nusantara literary scripts can be categorized into four periods. First, the scripts containing the original stories of Nusantara. Second, the Nusantara scripts filled with stories with an India-Hindu nuance. Third, the Nusantara scripts containing stories combining Hindu and Islamic nuances. Fourth, the Nusantara scripts with an Islamic nuance (see Effendi). Generally, the writing was known in Nusantara land when Hinduism began to spread. In this period, the stories with an India-Hindu nuance were circulated among the community.

After the arrival of Islam, the copying of scripts became popular. Moslem Nusantara litterateurs skillful in writing Arabic letters collectively copied many scripts they were familiar with. It did not matter whether it was original, Hindunuanced, or Islam-nuanced- everything was copied in the Arabic-Melayu or Jawi alphabets.

The scripts with an Islamic nuance written in the Jawi alphabet were known as literary books. Fang (1991) argued that literary books comprised of a wide range of studies, including about Alquran, interpretation, tajwid, broadcasts, ulIslam, proposals, fiqh, Sufi science, tasauf science, withdrawal, remembrance, rawatib, prayers, talismans, treatises, wills, dan the book of tib (medicine, incantations). Furthermore, the Jawi alphabet was not only used for literary books with a nuance of Islam but also for writing literary works with a nuance of Hindu (including Burung Simbangan Poetry). Jawi means the people of Java, including Melayu. Arabic people in the past considered Nusantara the island of Java. Therefore, the Melayu writing using Arabic letters was known as the Jawi alphabet (Isa, 1999).

The stories in Banjar scripts are mostly legends and myths. Legends are stories that are believed by the authors' society to be based on true events, while myths are stories that are also believed by the authors' society but are also considered sacred by the authors. The sacredness of the myth can be seen when the narrative begins with certain rites, such as burning incense and reciting prayers that have to be performed by the storytellers. Legendary and mythical stories are filled with pralogical aspects in which the stories are logical to the creators of the story yet illogical to others. These aspects include humans who are immune to weapons, weapons that launch fire, humans who can fly, etc. (Effendi, 2017). 
Liaw Yock Fang (1991) stated that there are few Siti Zubaidah Poetry scripts. The oldest script is stored in the SOAS library (MS 37083) dated 1256 H (1840 M). Siti Zubaidah Poetry has 3373 stanzas. Sayekti and Jaruki (2016) transliterated the script of Siti Zubaidah Poetry stored by a resident of Marabahan (Kalimantan Selatan). The script had been transliterated from the Jawi into the Latin alphabet by Irawan (2009).

\section{The Similarities Between Burung Simbangan Poetry And Siti Zubaidah Poetry}

Several similarities between the Burung Simbangan Poetry script and the Siti Zubaidah Poetry script are presented in this study.

\section{A. A Protagonist with Multiple Wives}

The protagonist in Burung Simbangan Poetry has a number of wives. Similar to that story, the protagonist in Siti Zubaidah Poetry also has a number of wives. However, the argument about this case has had different bases or reasons. In Hindu literature, having multiple wives was considered a prestige for a knight. A wife seized during a war, especially a war that involved many knights from different creatures (physical and spiritual creatures), raises the value of the knight. He would become very respectable and admirable. In the literature with a Hindu nuance, a knight can have as many wives as he wishes. This refers to the magical ability possessed by the knight. The more powerful he is, the more wives he can have.

Different from Islamic literature, marriage is conducted in order to fulfill the mandate of the Prophet Muhammad. The Prophet recommended or allowed men to have four wives on the condition that they act fairly toward their four wives.

The character in Burung Simbangan Poetry who has multiple wives was Wijaya Karti, who already had 39 mistresses and was seeking another to reach 40. The lyrics depicting the knight can be seen in the following Burung Simbangan Poetry.

\begin{tabular}{|l|l|}
\hline Original poetry & Meaning \\
\hline Wijaya Karti raja bestari & Wijaya Karti the powerful king \\
Tiga puluh sembilan ada berputri & Thirty-nine ladies are his own \\
Tetapi belum diambilnya istri & But not yet taken as wives \\
Karenalah lagi hendak mencari & So much to look for \\
& \\
Kuranglah satu barisi galuh & It still one more young lady \\
Lagi mencari seorang tubuh & More looking for a body \\
Hendak mencukupkan empat puluh & Want to make forty \\
Jadi mencari bersungguh-sungguh & So, he seek hardly \\
\hline
\end{tabular}

Another character in Burung Simbangan Poetry with multiple wives was Manik Suntana. Manik Suntana is the main character in this story and is described as having two wives: an unnamed one and a wife named Princess Gumilang Sari. Princess Gumilang Sari was obtained by Manik Suntana after he had defeated a number of knights who had also competed for her.

In Siti Zubaidah Poetry, it is mentioned that the protagonist, King Ahmad Syah, also has four wives. The happiness and harmony among these four wives are depicted in the following lyrical stanzas.

\begin{tabular}{|c|c|}
\hline Original poetry & Mean \\
\hline Raja Ahmad Syah terlalu suka & King Ahmad Shah too much love \\
\hline Beroleh istri elok belaka & Got beautiful wives \\
\hline Sama tak jemu dipandang mata & Similarly, all are nice see \\
\hline Keempatnya sama dikasihkan juga & The four were equally astonished \\
\hline Keempat putri terlalu suka & The four wives too much like \\
\hline Berkasih-kasih bagai saudara & Love each other like a sister \\
\hline Putri Rahmah pandai memelihara & Princess Rahmah expert in preserving \\
\hline Mengikuti perangai bunda saudara & Follow her mother's attitude \\
\hline Terlalu kasih akan madunya & Too much love for her concubines \\
\hline Tidak bercerai keempatnya & The fourth no divorce \\
\hline Terlalu sangat baik hatinya & Too very good-hearted \\
\hline Laku Zubaidah habis diturutnya & Zubaidah's conduct was followed over \\
\hline
\end{tabular}

\section{B. The First Wife Assisting Her Husband in War}

In Burung Simbangan Poetry, Lord Manik Suntana and his four commanders were defeated in a war against Wijaya Karti. Manik Suntana, who rode a white tiger, was pierced by Wijaya Karti's arrow. The arrow turned into a chain and bound him and his white tiger. Manik Suntana then fell down into the wilderness.

In his plight, Manik Suntana removed a bunch of flowers from a pouch. The flowers turned into a lady (who is Manik Suntana's first wife). She was sad to see her husband in that state. He told her what had happened to him. Upon hearing his story, she was also engulfed in this sadness and was willing to assist him in a war to reclaim his young wife. 
Eventually, the war was won by Manik Suntana, thanks to the help of his powerful first wife (oldest wife). The event of the oldest wife assisting her husband in a war in Burung Simbangan Poetry is depicted as follows.

\begin{tabular}{|c|c|}
\hline Original poetry & Meaning \\
\hline Macan putih Manik Suntana & White Tiger of Manik Suntana \\
\hline Terlalu sangat gundah gulana & Over of upset \\
\hline Panah rantai itu terkena & Both were shot by an arrow conjured a chain \\
\hline Jatuh malayang ke sini sana & Fall float zig zag \\
\hline \multicolumn{2}{|l|}{ Ia pun jatuh ka tangah hutan } \\
\hline Dibawa panah yang kasaktian & They fell down into the wilderness Dragged by a magic arrow \\
\hline Hati di dalam tarlalu rawan & His heart too vulnerable \\
\hline Air matanya jatuh barhamburan & The tears fell down scattered \\
\hline Gundah sangat tiada terpari & His deep sorrow imperceptible \\
\hline Di dalam hutan seorang diri & In the woods alone \\
\hline Kembang diungkai dengan lestari & Flowers taken out from the pouch \\
\hline Lalulah hidup menjadi putri & Then transformed into a princess \\
\hline \multicolumn{2}{|l|}{ Tuan putri sakit hatinya } \\
\hline Melihatkan hal itu suaminya & The Princess hurts hearted \\
\hline Lalulah segera ia bartanya & To see the state of her husband \\
\hline Apakah kakang asal mulanya & She immediately asked \\
\hline Manik Suntana menyahut perlahan & What happened my dear \\
\hline \multicolumn{2}{|l|}{ Berbagai warna yang dikatakan } \\
\hline Sedikit tiada yang bertinggalan & Manik Suntana responded slowly \\
\hline \multirow[t]{2}{*}{ Putri mendangar belas kasihan } & Various colors were said \\
\hline & Not a bit left behind \\
\hline Tuan putri berhati goyang & She heard lovingly \\
\hline \multicolumn{2}{|l|}{ Ia berkata pada sekarang } \\
\hline Katanya aduh paduka kakang & The princess heart swung \\
\hline \multirow[t]{2}{*}{ Adinda hendak turut berperang } & She said at present \\
\hline & She said oo...my honey \\
\hline Tuan putri intan habandung & Let your lover leave for fighting \\
\hline \multicolumn{2}{|l|}{ Anaknya ajar meminta tolong } \\
\hline Bersaru-seru mintalah tolong & Princes Intan is akin a beautiful painting \\
\hline Kedengaran ka surga & She begged to the God \\
\hline \multirow[t]{2}{*}{ Kayangan Mendung } & Ask for help \\
\hline & Her voices reached heaven \\
\hline Sakalian Dewa membari berkat & Creating a cloud \\
\hline \multicolumn{2}{|l|}{ Rantai hilang pada sesaat } \\
\hline \multicolumn{2}{|l|}{ Manik Suntana sukanya sangat } \\
\hline Lalulah segera hendak berangkat & The Gods bless her \\
\hline Terlalu suka di dalam dada & The chain disappeared flashy \\
\hline Istrinya dipeluk dicium serta & Manik Suntana was very happy \\
\hline Jika tiada emas adinda & Leaving the wilderness immediately \\
\hline Pastilah mati badan kakanda & Too much glad in the heart \\
\hline & His wife was hugged and kissed \\
\hline & If no gold were yours \\
\hline & Certainly, I became a dead body \\
\hline
\end{tabular}

In Siti Zubaidah Poetry, King Zainal Abidin's wife, Siti Zubaidah, came to free him and his four commanders who were taken hostage by seven Chinese princesses. Thanks to her help, King Zainal Abidin and his four commanders were freed and won the war. In attempts to free her husband, Siti Zubaidah disguised herself as a man named Syahar. Syahar was accompanied by her best friend, Rukayah Putri. Rukayah also disguised herself as a man named Nahar. The event is narrated in Siti Zubaidah Poetry as follows.

\begin{tabular}{|c|c|}
\hline Original poetry & Meaning \\
\hline Syahar itu sangat gagahnya & Shahar looked very gallant \\
\hline Kunci besi dapat dipatahkannya & The iron lock can be broken \\
\hline Sama sekali dibukakan semuanya & Absolutely everything was open \\
\hline Terlalu suka di dalam hatinya & Too much love in his heart \\
\hline Setalah pintu sudah terbuka & After the door was open \\
\hline Tampaklah wajah sultan paduka & Looks at the face of the lord \\
\hline Tanda yakin cahaya di muka & The signs are sure to light up in advance \\
\hline Separti kuning tampaknya juga & Yellow spots seem to be as well \\
\hline Syahar pun tidak terpandangkan & Shahar was not seen \\
\hline Kepada Nahar disuruh ambilkan & He asked Nahar to take \\
\hline Coba Adinda tolong ambilkan & Please bring me something \\
\hline Biar Kakanda menyambutnya tuan & Let me greet the master \\
\hline
\end{tabular}

\section{A First Wife Disguises Herself as a Man}


In the attempt to assist her husband to win the war in both in those examples, the protagonists' wives disguised themselves as men. The disguise of Manik Suntana's wife is narrated in Burung Simbangan Poetry as follows.

\begin{tabular}{|l|l|}
\hline Original poetry & Meaning \\
\hline Tuan putri muda perlinti & Young Princess of a pearl \\
Menyipat meng-Ajar dewa yang sakti & Prya to the almighty God \\
Menjadikan diri laki-laki & To turn him into a man \\
Pantas manis bukan separti & Her appearance is completely akin to a man \\
& \\
Putri meski suka dan riang & Princess felt likes and cheerful \\
Bagaikan pakaian lanang-lanang & Like a man's clothes \\
Pantas manis bukan kepalang & Her appearance is unbelievable \\
Memakai senjata tumbak dan parang & Holding a spear and a machete \\
\hline
\end{tabular}

In Syair Siti Zibaidah, she disguised herself as a man, as narrated below.

\begin{tabular}{|c|c|}
\hline Original poetry & Mean \\
\hline Kata orang yang punya madah & Says someone with flatter \\
\hline Kepada putri bermohon sudah & To the Princess begging something \\
\hline Lalu memakai paras yang indah & Then wear a beautiful face \\
\hline Separti laki-laki pakaian berpindah & As far as male cloak is moving \\
\hline Lalu berjalan dengan segera & Then walk right away \\
\hline Ke negri Yunan muda perwira & To the Yunan country as a young soldier \\
\hline Langsung masuk ke dalam negara & Jump directly into the country \\
\hline Mendapatkan maharaja putra & Got the emperor \\
\hline Hamba ini tidak berbanyak kata & I do not say too much \\
\hline Sudah tertangkap raja yang jaya & Have catch by a glorious king \\
\hline Ke dalam penjara dimasukkan serta & Thrown into the jail \\
\hline Zubaidah konon menggantikan tahta & Zubaidah supposedly ascended the throne \\
\hline Akan Zubaidah muda bangsawan & Will Zubaidah young patrician \\
\hline Bergantilah nama Syahar Pahlawan & Replace her name with Syahar the hero \\
\hline Adil dan murah barang kelakuan & Fair and cheap behavior \\
\hline Kasih kepada teman dan kawan" & Love to friends and companions \\
\hline Adapun Rukayah putri yang pauta & The Rukayah princess akin a beautiful painting \\
\hline Nahar konon nama yang nyata & Nahar is supposedly her real name \\
\hline Bijak bestari jangan dikata & Unbelievable brilliant \\
\hline Seorang tidak tahu warta & One does not know the news \\
\hline
\end{tabular}

\section{A protagonist Imprisoned in a Poisonous Well}

In Burung Simbangan Poetry, it is mentioned that lord Manik Suntana and his four commanders are put in a prison in the form of a well filled with poison. The prison is locked with three layers and guarded by an army. In Siti Zubaidah Poetry, it is mentioned that King Zainal Abidin and his four commanders are captured by Chinese princesses and then put into a prison with a steel door, wherein flows a deadly poisonous well.

The event of Manik Suntana being thrown into a prison full of poison is related as follows.

\begin{tabular}{|l|l|}
\hline Original poetry & Meaning \\
\hline $\begin{array}{l}\text { Manik Suntana sudahlah dapat } \\
\text { Sertalah patih yang berempat }\end{array}$ & $\begin{array}{l}\text { Manik Suntana already got } \\
\text { Accompany by his four commanders } \\
\text { Ke dalam kunjara itu dibuat }\end{array}$ \\
$\begin{array}{l}\text { The five were then tied } \\
\text { Thrown into the jail }\end{array}$ \\
$\begin{array}{l}\text { Sudah dibuat ke dalam penjara } \\
\text { Serta dikunci berlapis tiga } \\
\text { Balatentara suruh berjaga }\end{array}$ & $\begin{array}{l}\text { Already made into prison } \\
\text { An old toxic poison was put inside }\end{array}$ \\
$\begin{array}{l}\text { Amarah segala menteri dipati } \\
\text { Menjaga keranda malamnya hari } \\
\text { Setelah sampai ke tujuh hari }\end{array}$ & $\begin{array}{l}\text { And the guard queue outside } \\
\text { Dibuang ke laut dengan lestari }\end{array}$ \\
\end{tabular}

In Siti Zubaidah Poetry, the event of King Zainal Abidin and his four commanders is depicted as follows. 


\begin{tabular}{|l|l|}
\hline Original poetry & Meaning \\
\hline Putri ketujuh mendengar katanya & The seventh Princess heard a news \\
Terlalu sangat malu rasanya & She was too shy about it \\
Raja Cina sangat murkanya & The King of China was very angry \\
Sambil bertitah dengan marahnya & Spoke his anger \\
& \\
Baiklah dia kita siksakan & Let us torture them \\
Ke perigi racun kita masukkan & Pour the poison into the well \\
Inilah baik kita balaskan & This is our revenge \\
Perkataan kita tidak diturutkan & Our words were not obeyed \\
& \\
Setelah didengar berenam putri & After hearing the six Princesses \\
Titah baginda raja bestari & The virtuous king commands \\
Berkata kepada segala menteri & Said to all commanders \\
Bawalah dia masukkan perigi & Bring him to the well \\
& \\
Baginda dibawa putri berempat & \\
Ke dalam taman pagar yang rapat & The king was transported by the four Princesses \\
Perigi racun penjuru empat & Inside the locked tightly garden \\
Berpintu besi dikunci rapat & Four corners of the poisonous well \\
\hline & Iron door locked closely \\
\hline
\end{tabular}

\section{E. A protagonist Hit by a Chained Arrow}

In Burung Simbangan Poetry, it is mentioned that Lord Manik Suntana and his four commanders were shot by a chained conjuring arrow by commander Ambak Sigara. In Siti Zubaidah Poetry, it is mentioned that king Zainal Abidin and his four commanders were hit by a chained arrow by a Chinese princess named Kilan Syamsu.

The event of the protagonists being shot by a chained arrow is narrated in Burung Simbangan Poetry as follows.

\begin{tabular}{|l|l|}
\hline Original poetry & Meaning \\
\hline Adapun Patih Ambak Sigara & As for commander Ambak Sigara \\
Melihat geger balatentara & Seeing his army in turmoil \\
Amarah patih tiada terkira & Infinite anger expressed \\
Bersemedi mengejar Dewa Batara & Meditate to God \\
& \\
Menjadikan asap di atas gagana & Make smoke beyond the ultimate cloud \\
Sampai kepada manik Suntana & Get to Manik Suntana \\
Gelap pandangan ke sini sana & Dark sight everywhere \\
Hatinya bimbang gundah gulana & His heart is doubtful and upset \\
& \\
Ambak Sigara semedi pulang & Ambak Sigara meditate back \\
Panah rantai segera ditenting & Chain arrows immediately appointed \\
Macan Putih hilang pemandang & The White Tiger lost sight \\
Laluh jatuh melayang-layang & Falling down hover \\
Macan Putih Manik Suntana & \\
Terlalu sangat gundah gulana & White Tiger of Manik Suntana \\
Panah rantai itu terkena & Too very doubtful and upset \\
Jatuh melayang ke sini sana & The chain's arrow hit them \\
\hline
\end{tabular}

In Siti Zubaidah Poetry, a similar incident was also experienced by the protagonist, king Zainal Abidin, and his four commanders. That event is depicted by Siti Zubaidah Poetry as follows.

\begin{tabular}{|l|l|}
\hline Original poetry & Mean \\
\hline Pikir putri di dalam hatinya & The princess thought in her heart \\
Raja Kumbayat sangat eloknya & Lord Kumbayat was very handsome \\
Dengan adinda sangat patutnya & With her is very well suited \\
Baik kuambil akan suaminya & Well I took as a husband \\
& \\
Baiklah aku menangkap dia & Well I caught him \\
Sayang hatiku membunuh dia & It is too pity to kill him \\
Parasnya elok bangsawan mulia & The noble aristocrat is exquisite \\
Seperti bulan purnama raya & Like the full moon \\
& \\
Jika sudah di dalam tanganku & If it is in my hand \\
Masakan tidak menurut kataku & Impossible did not follow me \\
Aku perbuat seperti saudaraku & I do like my brother \\
Terlalu berkenan rasa hatiku & Too much to feel my heart \\
& \\
Setelah dipikir sedalam-dalamnya & After a deep thought \\
Segera mengambil anak panahnya & Take an arrow immediately \\
Dipanahnya Jakfar serta keempatnya & Shooting Jakfar's and the fourth \\
Menjadi tali yang mengikatnya & Become a string that binds them \\
\hline
\end{tabular}




\section{F. A First Wife Assists in Reclaiming Her Husband's Young Wife Who Has Been Kidnapped}

In Burung Simbangan Poetry, it was narrated that a wife helps her husband fight to reclaim his young wife who has been kidnapped by the enemy. It was mentioned in Burung Simbangan Poetry that the young wife (second wife) of Manik Suntana was kidnapped by a powerful man named Lord Wijaya Karti. Manik Suntana was helped by his first wife to reclaim her. In Siti Zubaidah Poetry, the first wife, Siti Zubaidah, sincerely forgives the second wife's mistake and marries off her husband to two other ladies.

The event of a first wife assisting in reclaiming her husband's young wife who has been kidnapped is depicted in Burung Simbangan Poetry as follows.

\begin{tabular}{|c|c|}
\hline Original poetry & Meaning \\
\hline Ia pun terbang dengan bersegera & She flew in a hurry \\
\hline Mепији negeri Pasir Sigara & Lead up to the land of Pasir Sigara \\
\hline Tiada tersebut lagi antara & There is nothing between \\
\hline Bertemu kepada balatentara & Meet the army \\
\hline Berdua itu memandang ke tengah medan & The two looked at the battlefield \\
\hline Bertemu segala menteri sekalian & Meet all commanders \\
\hline Orang melihat tercengang heran & People look surprised \\
\hline Manik Suntana datang berkawan & Manik Suntana came to be a friend \\
\hline Tuan putri segera berubah & The princess soon changed \\
\hline Menjadikan dirinya sepucuk panah & Make herself as an arrow \\
\hline Mancur cahaya yang amat limpah & Emit sparkling light \\
\hline Siapa memandang berhati gundah & Who looks at the desperate \\
\hline Manik Suntana muda bestari & The young and brilliant Manik Suntana \\
\hline Memegang panah asalnya putri & Holding the arrows incarnation of the Princess \\
\hline Bersiku tunggal raden berdiri & Single angled the lord stands \\
\hline Panah dilepas dengan lestari & An arrow was shot precisely \\
\hline Seperti kilat panahnya terbang & The arrow flying like a flash \\
\hline Suaranya berdengung seperti kumbang & Its sound buzzed like a bee \\
\hline Terlalu takut senjata orang & Too afraid of people's weapons \\
\hline Semuanya pada masuk ke kumpang & It is all get into the machete holder \\
\hline
\end{tabular}

In Siti Zubaidah Poetry, the story of the first wife (Siti Zubaidah) who marries off her husband due to love and devotion to him, as well as to implement Islamic sunnah, is depicted by Siti Zubaidah Poetry as follows.

\begin{tabular}{|l|l|}
\hline Original poetry & Mean \\
\hline Demikian itu konon ceritanya & So, the story supposedly goes \\
Sultan Abidin dikawinkannya & The King Abidin was matchmade \\
Kilan Cahaya jadi istrinya & Kilan Cahaya becomes his wife \\
Sultan Yunan yang memberinya & Sultan Yunan as a matchmaker \\
\hline
\end{tabular}

Sultan Yunan was an alias for Siti Zubaidah disguised as a man. Therefore, king Abidin has three wives: Siti Zubaidah, Putri Sejarah, and Kilan Cahaya. After a few moments, he was married again by Siti Zubaidah. Siti Zubaidah's reason to do that again was for her husband to fulfill the Islamic sunnah, which allows men to have four wives. The story of Siti Zubaidah marrying off her husband can be seen in the following lyrical stanzas. 


\begin{tabular}{|c|c|}
\hline Original poetry & Meaning \\
\hline Adapun Zubaidah putri & As for Princess Zubaidah \\
\hline Berkata kepada suami sendiri & Says to her husband \\
\hline Hendak bekerja tujuhnya hari & Want to work seven days \\
\hline Menikahkan Tuan dengan Rukayah Putri & Get married the Lord with Rukayah Putri \\
\hline Putri Rukayah Laila yang pauta & Princess Rukayah Laila the beautiful akin a painting \\
\hline Dialah jadi saudaranya beta & She is become my sister \\
\hline Budinya banyak kepada kita & Her buddy is much to us \\
\hline Biarlah sama naik setahta & Let us get up the throne \\
\hline Baginda mendengar kata istri & The lord heard the wife say \\
\hline Baginda tersenyum manis berseri & He smiled sweetly \\
\hline Katanya wahai kemala negeri & He said, oh my country jade \\
\hline Sudahlah banyak kakanda beristri & I have a lot of wives \\
\hline Mohonlah kakanda tuan kurniakan & Ask your best friend \\
\hline Beristri tidak kakanda niatkan & Married do not your intension \\
\hline Tuan seorang sudah sangat kucitakan & Only you are my destiny \\
\hline Meskipun seribu istri tidak kusamakan & Although a thousand wives do not make me crazy \\
\hline Zubaidah tersenyum memandang muka & Zubaidah smiled at her face \\
\hline Sambil berkata lakunya suka & As she says he likes \\
\hline Istri kakanda barulah tiga & Your wife is only three \\
\hline Hukum syara sampaikan juga & Sunnah law recommends four \\
\hline Cukup empat apa salanya & What is wrong with four wives \\
\hline Karena laki-laki sudah adatnya & Because men have their custom \\
\hline Sunat konon mengikut nabinya & Sunnah was said to follow the prophet \\
\hline Janganlah pula mengurungkannya & Do not abandon it \\
\hline
\end{tabular}

\section{G. A Protagonist Accompanied by Four Loyal Commanders}

In Burung Simbangan Poetry and Siti Zubaidah Poetry, the protagonists were accompanied by four loyal commanders. In Burung Simbangan Poetry, the protagonist, Lord Manik Suntana, was accompanied by four commanders, and in Siti Zubaidah Poetry, the protagonist, King Zainal Abidin, was also accompanied by four commanders.

In Burung Simbangan Poetry, the protagonist, Manik Suntana, was accompanied by Patih Layang Tarbang, Simbar Gunung, Umbak Sigara, and Sangga Alam. The story of the four commanders who were loyal to the protagonist, Manik Suntana, is narrated in Burung Simbangan Poetry as follows.

\begin{tabular}{|c|c|}
\hline Original poetry & Meaning \\
\hline Adapun Patih Layang Terbang & As for commander Layang Terbang \\
\hline Di atas awan ia pun datang & Even beyond the cloud he came \\
\hline Tiada berpisah empat orang & No separation of four people \\
\hline Dengan segala senjata parang & With all the machete weapons \\
\hline Simbar Gunung Ombak Sigara & Simbar Gunung and Ombak Sigara \\
\hline Bersama terbang di atas udara & Together fly over the air \\
\hline Sangga Alam sama bermara & Sangga Alam move forward \\
\hline Berpisah dengan balatentara & Separated with their troops \\
\hline Patih yang empat di atas angkasa & The fourth commander on the sky \\
\hline Bertemu dengan Manik Suntana & Meet with Manik Suntana \\
\hline Sujud menyembah patih keempatnya & Praying to worship the fourth one \\
\hline Berkabar segala tingkah lakunya & Tell all stories \\
\hline Manik Suntana berkata perlahan & Manik Suntana said slowly \\
\hline Kitalah ini apa pikiran & This was what our mind is \\
\hline Tempat pencuri sudah ketahuan & The place of the thief was caught \\
\hline Putri pun sudah di dalam taman & The princess was already in the garden \\
\hline Keempat Patih menyembah sekarang & All commanders worship now \\
\hline Gustiku jangan berhati goyang & My Lord do not upset \\
\hline Ayo ke sana kita berperang & Let us go for fight \\
\hline Merebut putri intan dikarang & Snatch the Princess Intan at the rock \\
\hline
\end{tabular}

In Siti Zubaidah Poetry, the protagonist, King Zainal Abidin, was accompanied by four loyal commanders. They are Jakfar Sidik, Umar Baki, Abdullah Sani, and Muhammad Muhyidin. These four loyal commanders fiercely fight the Chinese army attacking the Kumbayat nation. The following lyrical stanzas depict their loyalty and heroism in protecting and fighting for the Kumbayat nation and their King. 


\begin{tabular}{|c|c|}
\hline $\begin{array}{l}\text { Jakfar Sidik segera berlari } \\
\text { Umar Baki wazir yang gahari } \\
\text { Abdullah Sani muda bestari } \\
\text { Terjun dari balairung sari }\end{array}$ & $\begin{array}{l}\text { Jakfar Sidik immediately ran } \\
\text { Umar Baki the vizier of the king } \\
\text { The young and brilliant Abdullah Sani } \\
\text { Plunge from the royal audience hall }\end{array}$ \\
\hline $\begin{array}{l}\text { Muhammad Muhyidin berdatang sembah } \\
\text { Kepada Baginda usul yang pitah } \\
\text { Ampun tuanku duli khalifah } \\
\text { Sekalian rakyat mau dikerah }\end{array}$ & $\begin{array}{l}\text { Muhammad Muhyidin come and pray } \\
\text { To his lord speak fluently } \\
\text { Mercy my lord oh your majesty } \\
\text { All the people want to be deployed }\end{array}$ \\
\hline $\begin{array}{l}\text { Jakfar dan Umar Abdulah serta } \\
\text { Masuk mengamuk memerang senjata } \\
\text { Tampik dan sorak gegap gempita } \\
\text { Laku seperti gajah yang meronta }\end{array}$ & $\begin{array}{l}\text { Jakfar and Umar Abdulah accompany } \\
\text { Enter the arena raging by holding weapons } \\
\text { The air was filled with the whoop and uproar } \\
\text { Akin a struggled elephant }\end{array}$ \\
\hline
\end{tabular}

\section{DISCUSSION}

The similarities between the scripts of Burung Simbangan Poetry and Siti Zubaidah Poetry indicate that one of them copied from or was influenced by the other. Looking at the genre, Burung Simbangan Poetry, whose genre is myth, existed before Siti Zubaidah Poetry, whose genre is legend. As seen from the aspects influencing the narrative, Burung Simbangan Poetry was influenced by Indian Hindu literature, which existed before Siti Zubaidah Poetry, which was influenced by Transitional Period literature, which was a transition from Hindu to Islamic society.

There are some indications that Burung Simbangan Poetry was a literary work with India-Hindu influence. This indication comes from the existence of (i) characters mediating to obtain supernatural powers, (ii) characters who can fly skillfully, (iii) a journey to choose a husband, (iv) the vicious Garuda bird, (v) utilization of magical tools, including arrow, mace, сири (hole of mast), etc., (vi) stories about Gods and their powers in governing the universe, and (viii) stories about spiritual creatures, such as ghosts, giants (Djamaris, 1989).

If Burung Simbangan Poetry was an India-Hindu-influenced myth, then Siti Zubaidah Poetry was a transitionalperiod-influenced legend. Some indications of the latter are: (i) a very vivid Islamic nuance, such as characters proficient in reciting the Quran, religious characters, etc.; and yet, (ii) there is still an India-Hindu nuance, such as characters who mediate, who can fly skillfully, and the use of isim (incantations or mantra) used as a talisman or to cleanse the body from poison.

The similarities elaborated above can support the existence of a similar contextual content in both forms, which is predicted because Siti Zubaidah Poetry was influenced by Burung Simbangan Poetry, which has nuances of IndiaHindu influence. In other words, Siti Zubaidah Poetry was a literary work of the Transitional Period, which was a transitional period from an India-Hindu influence to the Islamic literary age.

The existence of similarities between Burung Simbangan Poetry and Siti Zubaidah Poetry come from Siti Zubaidah Poetry having adopted some parts of the narrative of Burung Simbangan Poetry. This narrative adoption occurred because Siti Zubaidah Poetry was a literary work of the Transitional Period, one easily compared to the literary work of the Hindu Period. In the Transitional Period, the Moslem population of Indonesia did not have their own literary works, so that Indian-Hindu literature was adopted first and or treated as a source of inspiration in writing literary works.

Similarities between literary and cultural works often occur in the history of world literature. The most popular example is the similarity in literary ideas that elevates the forbidden love story, for example between Romeo and Juliet and between Layla and Majnun. This similarity can occur because of the existence of archetypes, along with personal memories and experiences common to all humanity. This idea becomes a part of universal unconscious. These archetypes are shared by all cultures, independent of time and place (Avci, 2016).

In the Indonesian context, the influence of Hindu literature on Islamic culture is very strong, especially in Java. This can be seen from the influence of the Mahabarata and Ramayana stories, which are then manifested in the form of puppet performances. The puppets, introduced in 1443 by Sunan Kalijaga, tell the stories of the Mahabarata and Ramayana. However, all literalism is thus transcended into universalism, with a strong component of indigenous cultural values. The new Muslim community in Java reinterpreted particular episodes (plays) and characters in terms of Islam (Yousof, 2010).

\section{CONCLUSION}

Similarities between Burung Simbangan Poetry and Siti Zubaidah Poetry stem from Siti Zubaidah Poetry adopting some part of the narrative of Burung Simbangan Poetry. This narrative adoption occurred because Siti Zubaidah Poetry was a literary work of the Transitional Period, one that was more easily compared to the literary works of the Hindu Period. In the Transitional Period, the Muslim population of Indonesia did not have their own literary works, so IndianHindu literature was adopted first and or treated as a source of inspiration in writing literary works.

The similarities between Burung Simbangan Poetry and Siti Zubaidah Poetry are (i) stories about romantic polygamy and living in harmony, (ii) stories about the first wife (oldest wife) assisting her husband in war so that he can win it, (iii) stories about the first wife disguised as a man, (iv) stories about a protagonist who is imprisoned in a poisonous well, (v) 
stories about a protagonist who is hit by a chained arrow, (vi) stories about the oldest wife assisting her husband in claiming his young wife who is kidnapped by the enemy, and (vii) stories about a protagonist accompanied by four loyal commanders.

\section{REFERENCES}

[1] Avci, N. (2016). Forbidden Love of Shakespeare's Romeo and Juliet and Fuzûlî’s Layla and Majnun. International Journal of Literature and Arts, 4(1-1), 1-4.

[2] Baried, B. S. (1985). Pengantar teori filologi. Jakarta: Center for Language Development.

[3] Djamaris, E. (1989). Antologi Sastra Indonesia Lama 1. Jakarta: Department of Education and Culture.

[4] Effendi, R. (2017). Unsur pralogis dalam Syair Burung Simbangan. Jurnal Bahasa, Sastra, dan Pembelajarannya 7.1, $145-156$.

[5] Fang, L.Y. (1991). Sejarah kesusastraan Melayu klasik. Jakarta: Erlangga.

[6] Ikram, A. (1997). Filologia Nusantara. Jakarta: Pustaka Jaya.

[7] Irawan, S. (2009). Syair Siti Zubaidah. Banjarmasin: CRDS.

[8] Isa, M.M. (1999). Sastera Melayu klasik bercorak Islam. Kuala Lumpur: Universiti Sains Malaysia.

[9] Krippendrorff, K. (2004). Content analysis: an introduction to its methodology. Thousand Oaks: SAGE Publication.

[10] Ricoeur, P. (Translated: Hery, M.). (2012). Teori Interpretasi. Jogjakarta: IRCiSoD.

[11] Robson, S.O. (1994). Prinsip-Prinsip filologi indonesia. Jakarta: Center for Language Development \& Universitas Leiden.

[12] Sayekti, S., \& Jaruki, M. (2016). Syair Siti Zubaidah. Jakarta: Language Center, Ministry of National Education.

[13] Sudjiman, P. (1995). Filologi Melayu. Jakarta: Pustaka Jaya.

[14] Yousouf, G.S. (2010). Islamic Elements in Traditionel Indonesia and Malay Theatre. Kajian Malaysia, 28.1, 83 - 101.

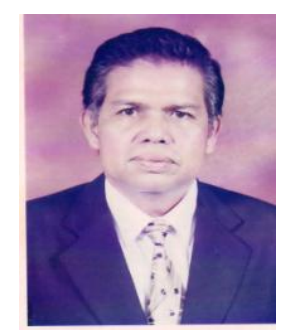

H. Rustam Effendi, M.Pd., Ph.D., is a professor at the Faculty of Teacher Training and Education (FKIP) Lambung Mangkurat University (Unlam), Banjarmasin, Study Program of Indonesian Language and Literature Education. He was Dean in FKIP Unlam (1999-2003 \& 2003-2007) and as the Leader of the Research Project of Indonesian Language and Literature, the Province of South Kalimantan. He completed his Bachelor (B.A.) in Lambung Mangkurat University, Banjarmasin, bachelor (Drs.) in State University of Malang, Master (M.Pd.) in Lambung Mangkurat University, and Doctor (Ph.D.) in Universiti Utara Malaysia, Kedah, Darul Aman in Applied Linguitics. Among his works are published in several journals such as International Journal of the Malay World and Civilisation, Universiti Kebangsaan Malaysia (2014); Man in India (2016); Mediterranean Journal of Social Sciences Vol 8, May 2017, Rome-Italy. He is also a frequent speaker at national/ international seminars/conferences. In August 2018, the paper titled Nonlinguistic Problems in Teaching of Indonesian Language included in the International Conference on Humanities \& Social Sciences di Universiti Teknologi Petronas, Malaysia. Rustam Effendi wrote several books, among them Sastra Banjar Pengaruh India-Hindu Syair Burung Simbangan (2017), Tema dan Amanat Legenda Banjar (co-author: Jumadi, 2016), Sastra Banjar Teori dan Interpretasi (2014). In professional organizations, Rustam Effendi became Chair of the Indonesian Literature Scholarship Association (HISKI) Commissariat Unlam (2006-2010) and the Executive Board of the Indonesian Literature Association (HISKI) Pusat, Jakarta (2010 - 2014). 